\title{
Efektivitas Pemanfaatan Getah Bunga Kamboja untuk Menghilangkan Sakit Gigi di Masa Pandemi COVID-19 (Kajian Pustaka)
}

\author{
I Made Budi Artawa ${ }^{1}$, Ni Made Sirat ${ }^{2}$ Ni Nyoman Dewi Supariani ${ }^{3}$ \\ Dosen Jurusan Kesehatan Gigi Poltekkes Kemenkes Denasar \\ Email: imadebudiartawa@gmail.com
}

\begin{abstract}
Toothache is an acute pain condition that requires immediate treatment. One of the herbal ingredients to treat toothache is frangipani flower sap because it is believed to contain anti-pain compounds such as alkaloids, tannins, flavonoids and tritepenoids which also function as antibiotics. Scientific evidence regarding the safety and effectiveness of using frangipani flower sap must be known so that the author is interested in writing "Is frangipani flower sap effective for overcoming tooth pain during the covid-19 pandemic?" The purpose of this study was to determine the effectiveness of frangipani flower sap on tooth pain during the covid-19 pandemic. Research method with literature study. By reviewing various previous research results that already exist, both from books and journals that are relevant to the problem, then they are discussed and conclusions are made. This research was conducted in 2021. Results and discussion, Sriwarthini NLPN et al., 2017 research results found that all concentrations of frangipani sap ethyl acetate extract ranging from 5, 20, 35, 50 and $65 \%$ were effective in inhibiting the growth of pathogenic fungi and forming an inhibition zone included in very strong category. The results of the research by Sukarjati, 2013 showed that the concentration of frangipani sap extract had a significant effect $(\mathrm{P}<0.05)$ on the growth of $\mathrm{S}$. aureus. The highest power of frangipani sap extract on the growth of $S$. aureus was obtained at a concentration of $25 \%$. The results of Heyne's research, 1987 The frangipani sap is useful as a pain reliever due to cavities, treats swollen gums and can ripen ulcers. The results of the research by Sulistyarsi, 2012 showed that there were differences in the inhibition zone of frangipani leaf extract against $S$. aureus $\mathrm{p}$ value $=0.01<0.05$. In the inhibition test, better results were obtained against Staphylococcus aureus bacteria with the lowest concentration of $25 \%$ and the inhibition zone of $23.66 \mathrm{~mm}$. Sirisha, 2014 frangipani sap extract has analgesic and antibacterial and antifungal effects. The frangipani extract contains alkaloids, flavonoids, saponins, steroids, tannins, glycosides and carbohydrates. Flavonoids and tannins dictate the role of pain inhibitors. This mechanism is driven by its effect as a prostaglandin inhibitor. The presence of active compounds in frangipani sap can reduce nociceptor activity on the tooth surface so that it can temporarily reduce pain. The conclusion is that frangipani flower sap is a safe, inexpensive and effective alternative to toothache treatment for treating acute toothache without complications in patients during the COVID-19 pandemic era.
\end{abstract}

Keywords: cambodia gum, toothache. Covid-19 


\section{Pendahuluam}

Wabah penyakit Corona Virus Disease (COVID-19) yang muncul pada akhir tahun 2019 di Wuhan Cina telah menyebar di seluruh negara menyebabkan angka kesakitan dan kematian yang tinggi. Per bulan Juli 2021 telah tercatat sebanyak 100 juta lebih kasus COVID-19 di seluruh dunia dan lebih dari 2 juta kasus di Indonesia ${ }^{1}$ Adanya wabah yang kian meningkat menyebabkan pemerintah menerapkan kebijakan 3M yaitu memakai masker, mencuci tangan dan menjaga jarak (KPCPEN, 2021). Kebijakan menjaga jarak sangat berdampak di semua bidang kehidupan termasuk kesehatan gigi. Tenaga pelayanan kesehatan gigi seperti Dokter gigi serta Terapist gigi dan mulut tidak luput dari dampak yang diakibatkan oleh virus ini karena penularannya dapat melalui pelepasan aerosol (penggunaan bur, alat ultrasonik, water/air syringe) dan percikan (droplet) air liur maupun darah dari rongga mulut pasien. Selain itu risiko infeksi dapat berasal dari ruangan praktek. Sehingga pemerintah menghimbau agar dokter gigi tidak melakukan praktik terlebih dahulu ${ }^{2}$

Keterbatasan praktik dokter gigi dan ketakutan pasien ke dokter gigi menyebabkan pasien yang mengalami masalah gigi seperti sakit gigi kesulitan memperoleh akses pemeriksaan di dokter gigi. Tidak hanya itu, kunjungan pasien untuk pembelian obat penghilang rasa nyeri ke apotek atau praktik tenaga kesehatan pun menjadi berkurang oleh karena ketakutan pasien berkunjung ke tenaga kesehatan. Padahal sakit gigi merupakan kondisi nyeri akut yang membutuhkan penanganan secara segera karena bila tidak, hal ini dapat menggangu kualitas hidup pasien. Berdasarkan data The Global Burden of Disease Study 2016 masalah kesehatan gigi dan 
mulut khususnya karies gigi merupakan penyakit yang dialami hampir dari setengah populasi penduduk dunia (3,58 milyar jiwa). Penyakit pada gusi (periodontal) menjadi urutan ke 11 penyakit yang paling banyak terjadi di dunia. Hasil Riset Kesehatan Dasar (Riskesdas) tahun 2018 menyatakan bahwa proporsi terbesar masalah gigi di Indonesia adalah gigi rusak/berlubang/sakit $(45,3 \%)^{3}$. Hal tersebut menunjukkan bahwa keluhan sakit gigi merupakan masalah yang cukup tinggi dikeluhkan oleh masyarakat. Oleh karena itu dibutuhkan penanganan alternatif lain yang bersifat segera dan aman bagi pasien yang mengalami sakit gigi. Salah satu bahan herbal yang digunakan sejak dulu untuk mengobati sakit gigi adalah getah bunga kamboja karena dipercaya mengandung senyawa antinyeri seperti alkaloid, tanin, flavonoid dan tritepenoid yang juga berfungsi sebagai antibiotik. Bukti ilmiah mengenai keamanan dan efektifitas penggunaan getah bunga kamboja ini harus diketahui sehingga penulis tertarik untuk membuat tulisan ini. Sehingga yang menjadi permasalahan pada penelitian ini adalah “ "Apakah getah bunga kamboja efektif untuk mengatasi rasa sakit gigi di masa pandemi covid-19 ?" Tujuan penelitian ini adalah untuk mengetahui efektifitas getah bunga kamboja terhadap rasa sakit gigi di masa pandemi covid-19 ?" Adapun manfaat yang diharapkan dari penelitian ini adalah untuk memberikan informasi kepada masyarakat tentang pemanfaatan getah bunga kamboja terhadap rasa sakit gigi.

\section{Metode}

Cara penelitian dengan study literature. Metode studi litratur yaitu penelitian yang dilakukan oleh peneliti dengan cara mengumpulkan sejumlah buku , majalah, jurnal yang bekaitan dengan masalah dan tujuan penelitian, untuk mengungkapkan berbagai teori yang relevan dengan yang diteliti sebagai bahan rujukan dalam pembahasan hasil penelitian. metode penelitian dengan cara 
Dengan mengambil data di perpustakaan, membaca, mencatat dan mengolah (Daniel dan Warsiah). Penelitian ini dengan cara mengkaji berbagai literature yang sudah ada ,baik yang bersumber dari buku maupun jurnal yang relevan dengan permasalahan, kemudian dibahas dan dibuat simpulan.

\section{Hasil dan Pembahasan}

Penelitian sebelumnya yang terkait dengan manfaat getah kamboja untuk sakit gigi yang dilakukan oleh Badal MS tahun 2018 menggunakan metode penelitian eksperimen dengan percobaan lengkap menggunakan 4 perlakuan konsentrasi getah batang kamboja putih dan kontrol positif cakram kertas antibiotikco-amoxyclav $30 \mu \mathrm{g}$. Hasil penelitian menunjukkan bahwa getah batang kamboja putih dengan konsentrasi $20 \% \mathrm{~b} / \mathrm{v}, 40 \% \mathrm{~b} / \mathrm{v}$, $60 \% \mathrm{~b} / \mathrm{v}$, dan $80 \% \mathrm{~b} / \mathrm{v}$ tidak memiliki aktivitas antibakteri terhadap pertumbuhan bakteri Pseudomonas aeruginosa. $^{4}$

Sriwarthini NLPN, dkk, tahun 2017 melakukan penelitian dengan metode eksperimental untuk menguji daya hambat dengan mengukur diameter zona hambat ekstrak etil asetat getah kamboja terhadap pertumbuhan jamur patogen. Hasil penelitian menunjukkan bahwa seluruh konsentrasi ekstrak etil asetat getah kamboja mulai dari 5, 20, 35, 50 dan $65 \%$ efektif menghambat pertumbuhan jamur patogen dan membentuk zona hambat yang termasuk dalam kategori sangat kuat ${ }^{5}$

Sukarjati, 2013 melakukan penelitian menggunakan metode eksperimental dimana getah kamboja diekstraksi dengan kloroform dan difraksinasi dengan etil asetat. Konsentrasi ekstrak etil asetat getah $(0 \%, 5 \%, 10 \%, 15 \%, 20 \%$, dan 25\%) diujikan terhadap pertumbuhan bakteri $S$. aureus dengan metode hitungan cawan dan difusi agar. Hasil penelitian menunjukkan konsentrasi ektrak getah kamboja berpengaruh signifikan $(\mathrm{P}<0,05)$ terhadap pertumbuhan $S$. aureus. Daya ekstrak getah kamboja tertinggi terhadap pertumbuhan $\mathrm{S}$. aureus diperoleh pada konsentrasi $25 \% .^{6}$

Heyne, 1987 tinjauan kepustakaan Tanaman kamboja 
memiliki banyak manfaat, mulai dari akar, batang, getah, daun, kulit batang dan bunganya. Akar kamboja digunakan untuk mengobati kencing nanah, daun dapat mengobati bisul bernanah. Getah kamboja bermanfaat sebagai pengurang rasa sakit akibat gigi berlubang, mengobati gusi bengkak serta dapat mematangkan bisul ${ }^{7}$

$$
\text { Sulistyarsi, }
$$

melakukan penelitian eksperimental dengan menggunakan metode difusi sumuran. Ekstrak konsentrasi 75\%, $50 \%, 25 \%$, kontrol positif, kontrol negatif masing-masing sebanyak $2 \mu 1$ dimasukkan ke dalam lubang sumuran kemudian diinkubasi pada suhu $37^{\circ} \mathrm{C}$. Pengamatan dilakukan pada 48 jam. Hasil penelitian menunjukkan ada perbedaan zona hambat pada ekstrak daun kamboja terhadap bakteri S.aureus $\mathrm{p}$ value $=$ $0,01<0.05$. Pada uji daya hambat diperoleh hasil lebih baik terhadap bakteri Staphylococcus aureus dengan konsentrasi terendah $25 \%$ dan zona hambat $23,66 \mathrm{~mm}^{8}{ }^{8}$

Sirisha, 2014, melakukan penelitian eksperimental dilakukan terhadap tikus yang diinduksi nyeri dengan asam asetat intraperitoneal. Ekstrak kamboja memiliki efek anti nyeri. Administrasi ekstrak kamboja secara oral dapat menurunkan nyeri melalui pengamatan ada tidaknya kontraksi otot pada tikus ${ }^{9}$

Berdasarkan penelitian terdahulu menemukan bahwa esktrak getah kamboja memiliki efek analgetik dan juga antibakteri serta antijamur. Esktrak kamboja mengandung alkaloid, flavonoid, saponin, steroid, tannin, glikosida dan karbohidrat. Flavonoid dan tannin diktehaui berperan sebagai penghambat nyeri. Mekanisme ini dijalankan oleh efeknya sebagai penghambat prostaglandin. Adanya senyawa aktif pada getah kamboja dapat menurunkan aktivitas nosiseptor pada permukaan gigi sehingga dapat menurunkan rasa sakit secara sementara ${ }^{9}$

$$
\text { Penggunaan yang }
$$

disarankan adalah dengan cara mencuci batang kamboja kemudian mengambil getahnya lalu diambil menggunakan lidi kapas dan dioleskan pada permukaan gigi yang 
sakit sampai rasa nyeri berkurang.

Kandungan antibakteri pada getah kamboja juga bermanfaat untuk membunuh bakteri yang ada pada permukaan gigi yang berperan dalam proses infeksi lanjut. Namun cara ini bukan pengobatan baku emas bagi sakit gigi, pasien tetap disarankan untuk datang ke tenaga kesehatan gigi bila nyeri berlanjut untuk diperiksa ${ }^{9}$

Toksisitas getah kamboja dilaporkan berupa terjadinya ruam pada individu yang sensitif atau nyeri ringan pada perut bila tertelan, namun belum ada kasus definitive keracunan getah kamboja sehingga tergolong aman bila diaplikasikan secara topikal rongga mulut dalam takaran yang tepat ${ }^{10}$

\section{Simpulan dan Saran}

Getah kamboja dapat menjadi alternatif modalitas pengobatan sakit gigi yang aman dan murah serta efektif untuk mengatasi sakit gigi akut tanpa komplikasi pada pasien di era pandemi covid-19. Sehinga disarankan bagi masyarakat yang menderita sakit gigi untuk menggunakan bahan herbal seperti getah daun kamboja sebagai penanganan sakit gigi akut terutama pada masa pandemi covid-19.

\section{Daftar Pustaka}

1. Worldometer.2021.Coronavir us Cases.[Online] Tersedia: https://www. worldometers.info/ coronavirus

2. Louisa M, Budiman JA, Suwandi T, dkk.2021.Pemeliharaan

Kesehatan Gigi dan Mulut di Masa Pandemi COVID-19 pada Orang Tua Anak Berkebutuhan Khusus.Jurnal Abdimas dan Kearifan Lokal.2(1):1-10.

3. Kemkes.go.id.2021.Situasi Kesehatan Gigi dan Mulut 2019.[Online] Tersedia : Kementerian Kesehatan Republik Indonesia (kemkes.go.id)

4. Badal MS.2018.Uji Aktivitas Antibakteri Getah Batang Kamboja Putih (Plumeria acuminate W.T.Ait) terhadap Pertumbuhan Bakteri Pseudomonas aeruginosa.Politeknik Kesehatan Kemenkes Kupang. 
5. Sriwarthini NLPN, Jekti DSD, Sedijani P.2017.Uji Efektivitas Daya Hambat Ekstrak Etil Asetat Kulit Batang Kamboja (Plumeria acuminata, Ait.) Terhadap Jamur Fusarium oxysporum fsp. Cepae.Jurnal Biologi Tropis.17(1):37-42

6. Sukarjati,

Wahyudi.2013.Pengaruh Ekstrak Etil Asetat Getah Kamboja (Plumeria Acumenata W.T. Ait) Terhadap Pertumbuhan dan daya Hambat Bakteri Staphylococus aureus.Fakultas MIPA Universitas PGRI Adi Buana Surabaya.

7. Heyne, K. 1987. Tumbuhan Berguna Indonesia. Jilid III. Badan Litbang Kehutanan. Penerbit Yayasan Sarana Wana Jaya. Jakarta.1624-1625 Hargreaves KM, Cohen S,
8. 8. Sulistyarsi A, Chayani FM.2012. Uji Komparatif Ekstrak Daun Kamboja Putih (Plumeria Acuminata W.T.Ait) Sebagai Penghambat Pertumbuhan Bakteri Salmonella Typhosa dan Bakteri Staphylococcus Aureus (In Vitro).Prodi Pendidikan Biologi, Fakultas Keguruan dan IImu Perikanan, Universitas PGRI Madiun

9. Sirisha K, Rajendra Y, Gomathi P, Madhavi M, Himabindu G, Aparna Y.(2014). Comperative phytochemical and pharmacological evaluation of flowers of Plumeria rubra L. F. Rubra and Plumerua rubra $f$. Lutea. British Biomedical Buletin. 2014;2(1):49-57

10. USDA, 2021.Poisonous PlantsPlumeria Rubra.[Online] Tersedia : Forest Service Nature (usda.gov) 